\title{
Importance of the signals provided by the buck for the success of the male effect in goats
}

\author{
J. Alberto DelgadiLlo*, J. Alfredo Flores, Francisco G. VÉLIZ, \\ Gerardo DUARTE, Jesús VIELMA, Horacio HERNANDEZ, \\ Ilda G. FERNANDEZ
}

\begin{abstract}
Centro de Investigación en Reproducción Caprina, Universidad Autónoma Agraria Antonio Narro, Periférico Raúl López Sánchez y Carretera a Santa Fe, CP 27054, Torreón, Coahuila, México
\end{abstract}

\begin{abstract}
Under temperate and subtropical latitudes, ewes and goats display a reproductive seasonal pattern and their sexual activity during the anestrous period can be stimulated and synchronized by the introduction of males in the group, which is called the "male effect". The response of females to the male effect in the middle of the anestrous season is weak or absent. This failure may be due to the inability of the female to respond to males, as a result of a refractoriness of the female to the male stimulus. But, it may also be due to a low quality stimulus provided by the male which is, as the females, in seasonal rest. We tested this latter hypothesis in seasonally inactive goats kept under subtropical conditions by comparing the use of males with their sexual behavior stimulated or not by photoperiodic treatments. Treated males were able to induce estrous activity of females during the whole anestrus season. We have also determined that previous separation of the males and continuous contact during teasing are not absolute requisites when active bucks are used. While odor from the male and its sexual behavior play a primary role in inducing ovulation, vocalizations appear to facilitate the display of the does' estrous. It remains to be determined to which extent these conclusions apply under temperate latitudes and with more seasonal breeds.
\end{abstract}

goat / male effect / buck vocalizations / male odor / sexual behavior / photoperiodic treatment

\section{INTRODUCTION}

The social interactions between partners of the same species may lead to important changes in their reproductive status [1]. Exposure of seasonally anovulatory goats and ewes to males can stimulate and synchronize their sexual activity $[2,3]$. This phenomenon of sexual biostimulation is known as the "male effect" or "teasing" and has been extensively studied in goats and sheep $[4,5]$. In these species, the response of females to the introduction of males involves a rapid increase of luteinizing hormone $(\mathrm{LH})$ secretion that culmi-

*Corresponding author: joaldesa@yahoo.com nates in a preovulatory surge provoking ovulation $[6,7]$. In sheep the first ovulation is not accompanied by behavioral estrus whereas in goats, a variable number of females show estrus behavior at the first induced ovulation 2-4 days after male introduction. Most goats have a short ovarian cycle of 5-7 days of duration, followed by a second ovulation, which is associated with estrous behavior and a normal luteal phase $[2,8]$. Ewes may, however, also show a short cycle, but it is only after the first cycle of normal length that they display estrus. The characteristics of the response of females to teasing are variable and may depend on several internal and external 
factors operating in both sexes, such as the variation of the females' responsiveness to the presence of males because of the photoperiod, genetic factors, or the quality of the stimulus provided by the males [9]. In this article, we focus only on the role of the male, with the aim of underlining the importance of the sexual behavior showed by the males during teasing. In the first part of the paper we summarize the factors from males that are classically considered important when using the male effect under natural conditions (i.e. with no or minimal preparation of the males). In the second part, we review the specific situation of the male effect in goats under subtropical conditions, which illustrates the importance of using adequate males for the success of teasing.

\section{FACTORS FROM THE MALE INFLUENCING THE RESPONSE TO THE MALE EFFECT UNDER NATURAL CONDITIONS}

In sheep and goats, the quality of the stimulation depends at least on the degree of contact between the two sexes, previous separation between sexes, duration of contact and the intensity of the sexual behavior of the males [9].

\subsection{Degree of contact between the two sexes}

The degree of contact between the two sexes may affect the response of the females to the male effect. Pearce and Oldham [10] exposed ewes to various degrees of contact with rams (e.g. full physical contact, contact through an openwork fence, contact through an opaque fence, contact with rams' wool in facial masks or complete isolation from males). Contact through an opaque fence was less effective than through an openwork fence, and the maximum effect was achieved in all cases when the ewes were allowed full physical contact with the males. In Angora goats, $41 \%$ of 85 does separated from bucks by a wire fence (weak stimulation) ovulated, compared with $69 \%$ (out of 66) when put in direct contact with the males (strong stimulation) [4]. In both ewes and goats, a high response of females is obtained when both sexes are in full physical contact, showing that the degree of response of the female is influenced by the type of contact with males.

\subsection{The duration of contact between sexes}

The duration of contact between the two sexes is another factor that influences the ovulatory response of the females. Even in females that are likely to respond to teasing (e.g. at the end of the non breeding season), the continued presence of the male is required to obtain a maximum ovulatory response, or to prolong the induced ovulatory activity $[6,11,12]$. In ewes, three hours of contact with rams induce a rapid increase of LH secretion but it is not enough to provoke ovulation [12]. Then, LH secretion returns to pre-stimulation levels after the male is removed. Signoret et al. [11] determined that the duration of contact also affects the percentage of females ovulating during the male effect. While only $20 \%$ of ewes ovulated when exposed to teasers for $24 \mathrm{~h}, 51 \%$ ovulated after 4 days of contact with males. Moreover, the percentage increased to $61 \%$ in females exposed to rams for 13 days [11]. In goats, while the exposure to males for $16 \mathrm{~h}$ per day during 10 days induced only $19 \%$ of goats to ovulate, the continuous exposure induced ovulation in $95 \%$ of them [13]. These results suggest that the continuous presence of males is required during at least 4 days to obtain a good response of females to teasing.

\subsection{Previous separation between sexes}

From early studies carried out in ewes, it was assumed that females must be 
preconditioned by a period of isolation of at least three weeks from males, to be able to ovulate in response to the reintroduction of other males $[14,15]$. Later, some results suggested that this separation may not be necessary and that in some cases ewes are able to respond to males without previous separation. For example, previous exposure to rams for $2-3 \mathrm{~h}$ did not affect the LH response of females when the males were re-introduced $24 \mathrm{~h}$ later [12]. In a similar way, in ewes in contact with rams, the introduction of new males induced ovulation in a similar percentage of females $(85 \%)$, than those that had previously been totally separated from the rams (86\%) [16]. Finally, in ewes, Pearce and Oldham [10] found that between $89 \%$ and $95 \%$ of ewes remaining in anestrus after 65 days in contact with rams, ovulated 4 days after the introduction of novel rams. However, these results should be carefully considered before assuming that the introduction of new males may not be effective in other breeds or periods.

\subsection{Intensity of libido of the males}

Several studies have indicated that the sexual behavior of the male is an important determinant of the response of females to the male effect. Androgen-treated castrated rams, who display intense sexual activity, induce ovulation more effectively than males given the same dose of androgen but which are relatively inactive [11]. Likewise, Fulkerson et al. [17] reported that wethers treated with testosterone or estradiol, who displayed higher sexual behaviors than untreated castrates, were more effective to induce a sexual activity in anovulatory ewes. Recently, Rosa et al. [18] found that stimulating sexual activity of rams through melatonin administration improved the ovulatory response to teasing (56\%), compared with that of ewes put in contact with non treated rams displaying a low sexual behavior (24\%). Perkins and Fitzgerald [19] compared the use of high or low serving capacity rams as teasers, obtaining a higher percentage of ewes ovulating with the first (78\% vs. $59 \%$ ). In goats, the bucks' libido also affects the response of females to the male effect. Well nourished bucks, who show a high sexual activity, stimulated estrous behavior in a higher percentage of anestrus does than undernourished bucks displaying a poor sexual activity (67\% vs. $38 \%$ ) [20].

\subsection{Sensory cues from the male involved in the male effect}

The male effect is a multi-sensory phenomenon involving olfactory, visual, tactile and auditory cues. High percentage of females respond to male stimulation when all cues are active [2, 4, 19, 21-23]. In ewes [21] and goats [24], olfactory cues from the male appear to be involved in mediating the male effect. In ewes, the male odor stimulates an increase of the frequency of LH pulses, and induces ovulation in a high proportion of them. However, in other trials a lower proportion of ovulating goats was obtained compared with those teasing with full male contact [13, 25]. However, in the dwarf Creole goat from the French West Indies Islands in the Caribbean, peripherally induced anosmia does not prevent the response to the male effect, although the proportion of females showing estrus or ovulation decreases $(50 \%$ in anosmic females vs. $89 \%$ control females) [7]. Overall, these results indicate that olfactory cues are involved in the response of females to the male effect, but whole male-female behavioral interactions are likely to play some stimulatory role.

Although in lower percentage than with full buck contact, some does ovulate in response to male odor and vocalizations (19.5\% vs. $41.2 \%)$ [4]. In the sow, 
vocalizations may compensate for the absence of olfactory signals and allow immobilization behavior of the female [26] Also, in birds, male courtship vocalizations have a stimulatory effect on ovarian activity [27, 28]. In the red deer (Cervus elaphus), the play-back of recorded vocalizations from males during courtship advanced the onset of the breeding season compared with that of isolated females [29].

\subsection{Limitations of the male effect}

A limitation for the practical use of the male is the wide variation of responses in relation to the moment of the anestrus period in which teasing is performed. That is more critical in strong seasonal breeds of sheep and goats. In such breeds, since the response of females is low or absent during mid-seasonal anestrus, the practical use of the male effect is limited to the period just preceding the onset of the normal breeding season $[2,6,30]$. However, in breeds exhibiting only a moderate seasonality such as the Merino sheep or Creole dwarf goats from the tropical Guadeloupe Island, the introduction of males induces an ovulatory response at most times of the non-breeding season $[31,32]$.

\section{THE USE OF THE MALE EFFECT IN THE GOAT UNDER SUBTROPICAL CONDITIONS}

There are at least two non exclusive hypotheses to explain for the poor efficiency of the male effect outside the limited period preceding the spontaneous onset of the breeding season. First, the inability of the female to respond to males due to a photoperiod-dependent refractoriness of the female to the male stimulus $[9,33,34]$. Second, it may be due to a low quality stimulus provided by the males which are, as the females, in seasonal rest. Indeed, during the non-breeding season, all sexual characteristics of rams and bucks decrease dramatically [35-37].

The limitation on the quality of the stimulus may be particularly important under latitudes where the photoperiodic inhibition of female activity is not too strong. Thus, studying the male effect in subtropical conditions offers a good opportunity to understand how the various sensory cues from the male interact to stimulate reproduction in anestrous females. This happens in local bucks from subtropical Mexico, which derive from the Spanish Granadina, Murciana and Malagueña breeds and crossed with Alpine, Saanen and AngloNubian breeds. These bucks have a well defined non-breeding season, which lasts from January to May-June. During this period, the plasma concentration of testosterone, the sexual behavior assessed by ano-genital sniffing, nudging and mounts and the sexual odor of bucks are at a low level $[8,38,39]$. We hypothesized that if the sexual characteristics of the bucks are improved by stimulating their sexual activity during the non-breeding season, males may be able to induce the sexual activity of females at any time during the seasonal anestrus period. Therefore, we developed photoperiodic treatments to stimulate the sexual activity of local bucks from subtropical Mexico, and tested the response of females exposed to treated males.

\subsection{Stimulation of the sexual activity of male goats during the period of seasonal sexual rest}

In Mexican bucks, photoperiod is the main factor determining the annual changes of sexual activity. While artificial treatments with short days stimulate reproductive activity, it is inhibited with long day-treatments [30]. In summary, in this breed, alternation of long and short 
days allows the controlling of the bucks' sexual activity. While long days may be provided by extra periods of illumination indoors or outdoors, short days can be mimicked by natural or artificial daylight, or by melatonin administration. In males kept indoors, 2.5 months of long days (16 h of light/day: lights-on $0600 \mathrm{~h}$, lights-off $2200 \mathrm{~h}$ ) starting on November 1 (mid-breeding season), followed by an application of two subcutaneous (s.c.) ear melatonin implants (18 mg each), induce an intense sexual activity during the nonbreeding season [40]. In treated males, testosterone secretion is higher than in controls from February to April (non-breeding season). Sexual behavior, assessed by anogenital sniffing, nudging and mounts, is also higher in light treated males exposed to anestrous female goats than in controls $[8,41]$. Similar results are obtained in males raised in open pens and subjected to 2.5 months of long days using a combination of natural and artificial illumination, followed by melatonin implants. In this case, artificial light is given from 0600 to 0900 and from 1800 to $2200 \mathrm{~h}$ to obtain $16 \mathrm{~h}$ of light/day [41,42]. Interestingly, in males raised in open pens and treated with 2.5 months of artificially long days only and no melatonin implants, testosterone secretion and sexual behavior are stimulated during the non-breeding season and do not differ from those of males receiving melatonin implants [42]. Finally, sexual activity of male goats maintained in constant long days (16 h of light/day) from November 1 to June 15, is stimulated from March to June [43]. In males submitted to constant long days, plasma testosterone concentrations increase in March, as in bucks treated with 2.5 months of long days followed or not by the insertion of 2 ear s.c. melatonin implants. However, testosterone plasma levels do not decrease in April as in bucks treated with 2.5 months of long days, but remain high until June. These treated males, display a more intensive sex- ual behavior than controls when exposed to estrous females [43].

These data show that in local male goats from subtropical Mexico, the alternation between long days and short days or melatonin implants, stimulates their sexual activity during the non-breeding season. These treatments can be applied in lightproof buildings or in open sheds using natural or artificial light and melatonin implants, improving all sexual characteristics of males during the non-breeding season. Those stimulated bucks may be effectively used as teasers.

\subsection{Response of female goats exposed to active males in different months of the non-breeding season}

Through several studies performed in our laboratory, we have demonstrated that bucks treated with long days and melatonin implants are able to stimulate the sexual activity of anestrous goats during the seasonal anestrous period [8, 41]. In March, bucks maintained in a light-proof building or in open sheds, treated with long days and melatonin, stimulated estrus in more than $80 \%$ of females, compared with $10 \%$ obtained when females were exposed to sexually inactive males $[8,41]$. Similar results have been obtained using bucks treated only with artificially long days. Indeed, all females (19/19) exposed to photoperiodic treated males were detected in estrus, while only $10 \%$ of these in contact with non-treated males displayed estrus [42]. Interestingly, those males treated with long days only were able to stimulate estrus in a higher percentage of females grazed in our extensive conditions $(85 \%)$ than sexually inactive males $(30 \%)$ [ 30 , 44]. Finally, bucks submitted to constant long days from November to June are also able to stimulate the sexual activity of does from April to June, during mid-seasonal anestrous [45-47]. In April, light-treated, 
sexually active males stimulated estrous behavior in a higher percentage of females $(90 \%)$ than non-treated, sexually inactive males $(0 \%)$. In contrast, in May or June the percentage of females displaying estrous behavior was similar with treated or untreated bucks. The lack of difference is likely to be due to the onset of the natural sexual activity in control bucks, which starts in May [39].

These results show that sexually active males are able to stimulate the sexual activity of does during the non-breeding season and suggest that, at least in our conditions, the sexual behavior of bucks is the main limitation for the efficacy of the male effect during the seasonal anestrus period.

\section{RECENT OUTCOMES FROM THE MALE EFFECT STUDIES OBTAINED IN GOATS}

The use of sexually active and inactive males as teasers gives the opportunity to determine the role of the different cues involved in the stimulating mechanisms. Thus, by comparing the response to teasing by sexually active or inactive males, we have determined the importance of buck odor, male sexual behavior, buck vocalizations, continuous presence of males and previous separation between sexes in the success of the male effect.

\subsection{Importance of buck sexual behavior and olfactory cues}

In sheep and goats it is well established that both sexual behavior and olfactory cues are involved in the response of the females exposed to the males $[9,21,25,48]$. Using sexually active and inactive males, we tested in vivo the role of these cues in the response of females to the male effect [49]. Two control groups of females ( $n=10$ each; 1 buck/group) were exposed to a sexually inactive buck, that was either awake or sedated in order to prevent the display of any male sexual behavior. Two other groups ( $n=10$ each, 1 buck/group) were exposed to a buck rendered sexually active by 2.5 months of long days (treated), also either awake or sedated, as in the control groups. Plasma LH concentrations were determined every $15 \mathrm{~min}$ for $4 \mathrm{~h}$ before and $4 \mathrm{~h}$ after male introduction, and again for $4 \mathrm{~h}$ on the next day. Regardless of whether they were awake or sedated, sexually active males stimulated LH pulsatility ( $2.7 \pm 0.2$ pulses $/ 4 \mathrm{~h}$ vs. $2.5 \pm 0.3$ pulses $/ 4 \mathrm{~h}$, respectively) in does. In contrast, in females exposed to sexually inactive males LH pulsatility was not increased (1.2 \pm 0.1 pulses $/ 4 \mathrm{~h}$ vs. $1.4 \pm 0.2$ pulses $/ 4 \mathrm{~h}$ ), regardless of whether bucks were awake or sedated. However, the following day, 20-24 h after male introduction, LH pulsatility remained high in does exposed to the awake sexually active male $(2.1 \pm 0.3)$, whereas in does exposed to the sedated sexually active male LH pulsatility had returned to levels that did not differ from those found before the introduction of the buck $(1.6 \pm 0.2$ vs. $1.1 \pm 0.1)$. These results suggest that in the first $4 \mathrm{~h}$ of contact between the male and females, olfactory cues alone are sufficient to trigger LH secretion. However, sexual behaviour of males seems important to maintain a high level of LH secretion for longer periods of time.

\subsection{Importance of buck vocalizations}

Some preliminary results from our laboratory suggest that buck vocalizations may stimulate estrus in local anovulatory female goats during the anestrous period [50]. One group of goats was joined with two sexually active bucks (SA group, $n=5$ ). The second group was exposed to buck vocalizations coming from the previous group (VOC group, $n=6$ ), reproduced through a microphone-amplifier- 
loudspeaker system. The third group was isolated from any male stimulus ( $\mathrm{C}$ group, $n=6$ ). The five females stimulated by bucks ovulated, whereas only $2 / 6$ did so in the VOC group and none in the control group (Fisher exact $\mathrm{Pb}=0.06$ and $=$ 0.002 ). However, the proportion of females displaying estrus did not differ between the does in contact with males $(5 / 5)$, and those submitted to male vocalizations $(5 / 6)$, and was higher in these two groups than in the isolated group $(0 / 6$, Fisher exact $\mathrm{Pb}<$ 0.02 ). These data suggest that male goat vocalizations may induce estrous activity in anestrous female goats, even though they do not seem to influence ovulation itself.

\subsection{Importance of the duration of contact between sexes}

Using sexually active males, we have demonstrated that the continuous presence of males until ovulation is not necessary to maximize the response to the male effect. Indeed, in local goats from subtropical Mexico exposed to bucks for $16 \mathrm{~h}$ per day, the percentage of females that showed estrous behavior $(96 \%)$ was similar to that of control females which were in contact with a male for $24 \mathrm{~h}(92 \%)$ [51].

\subsection{Importance of previous separation between sexes}

Early studies assumed that females must be preconditioned by a period of isolation from males in order to obtain a good ovulatory response $[5,15]$. However, recently we found in subtropical Mexican goats that maintaining contact with bucks does not induce refractoriness of females to the re-introduction of other males $[52,53]$. Indeed, when seasonally anovulatory goats were maintained in contact with a buck in sexual rest under natural photoperiod variations during three months before the male effect, the introduction of a sexually active male induced sexual behavior in $82 \%$ of females. This percentage did not differ from that registered in goats which had been totally separated from males before teasing during the same period of time $(91 \%)$. In contrast, when teasing was performed with bucks maintained under natural variations of the photoperiod - and thus inactive at the time of teasing - no females showed estrous behavior, regardless of whether they had been isolated or not from the buck before teasing. It remains to be tested if the previous presence of sexually active males affects the response to the introduction of other sexually active males. These results indicate that the previous isolation of seasonally anovulatory female goats from bucks is not critical to stimulate their reproductive activity by the male effect, if sexually active males are used, at least under our subtropical conditions.

\section{CONCLUSION}

The results obtained in our laboratory in goats underline the major importance of the quality of the males used for the outcome of the male effect. Although the type of goats used in these studies clearly show seasonal reproductive activity, the bucks' stimulation with photoperiodic treatments and melatonin administration ensures a proper activation of sexual behavior and production of sexual odors. As a result, very high rates of success in inducing estrus and ovulation can be obtained in goats in sexual rest. Indeed the use of active bucks allows disregarding many of the conditions that normally have to be taken into account for the success of teasing (e.g. time of the year, previous separation, continuous contact). It remains to be investigated to which extent this would also be true under more temperate latitudes and with more seasonal breeds. 


\section{ACKNOWLEDGEMENTS}

The authors are grateful to all students at the CIRCA for their participation in the experiments described in this paper. We also express our thanks to Pascal Poindron and Rodolfo Ungerfeld for critical comments that improved this manuscript and language corrections and to Dolores López for her secretarial assistance.

\section{REFERENCES}

[1] Bronson FH. Mammalian reproduction: An ecological perspective. Biol Reprod 1985, 32: 1-26.

[2] Chemineau P. Possibilities for using bucks to stimulate ovarian and oestrous cycles in anovulatory goats. A review. Livest Prod Sci 1987, 17: 135-147.

[3] Rosa HJD, Bryant MJ. The "ram effect" as a way of modifying the reproductive activity in the ewe. A review. Small Rumin Res 2002, 45: 1-16.

[4] Shelton M. Goats: influence of various exteroceptive factors on initiation of estrus and ovulation. Int Goat Sheep Res 1980, 1: 156162.

[5] Ungerfeld R, Forsberg M, Rubianes E. Overview of the response of anoestrous ewes to the male effect. Reprod Fertil Dev 2004, 16: 479-490.

[6] Martin GB, Oldham CM, Cognié Y, Pearce DT. The physiological responses of anovulatory ewes to the introduction of rams. A review. Livest Prod Sci 1986, 15: 219-247.

[7] Chemineau P, Levy F, Thimonier J. Effects of anosmia on LH secretion, ovulation and oestrous behaviour induced by males in the anovular Creole goat. Anim Reprod Sci 1986, 10: 25-132.

[8] Flores JA, Véliz FG, Pérez-Villanueva JA, Martínez de la Escalera G, Chemineau P, Poindron P, Malpaux B, Delgadillo JA. Male reproductive condition is the limiting factor of efficiency in the male effect during seasonal anestrus in female goats. Biol Reprod 2000, 62: 1409-1414.

[9] Walkden-Brown SW, Martin GB, Restall BJ. Role of male-female interaction in regulating reproduction in sheep and goats. J Reprod Fertil Suppl 1999, 52: 243-257.
[10] Pearce GP, Oldham DM. Importance of non-olfactory ram stimuli in mediating raminduced ovulation in the ewe. J Reprod Fertil 1988, 84: 333-339.

[11] Signoret JP, Fulkerson WJ, Lindsay DR. Effectiveness of testosterone treated wethers and ewes as teasers. Appl Anim Ethol 1982, 9: $37-45$.

[12] Cohen-Tannoudji J, Signoret JP. Effect of short exposure to the ram on later reactivity of anoestrous ewes to the male effect. Anim Reprod Sci 1987, 13: 263-268.

[13] Walkden-Brown SW, Restall BJ, Henniawati. The male effect in Australian cashmere goats 2. Role of olfactory cues from the male. Anim Reprod Sci 1993, 32: 55-67.

[14] Underwood EJ, Shier FL, Davenport N. Studies in sheep husbandry in Western Australia. V. The breeding season of Merino crossbred and British breed ewes in the agricultural districts. J Dep Agric West Aust 1944, 11: 135-143.

[15] Schinckel PG. The effect of the presence of the ram on the ovarian activity of the ewe. Aust J Agric Res 1954, 5: 465-469.

[16] Cushwa WT, Bradford GE, Stabenfeldt GH, Berger YM, Dally MR. Ram influence on ovarian and sexual activity in anestrous ewes: effects of isolation of ewes from rams before joining and date of ram introduction. J Anim Sci 1992, 70: 1195-1200.

[17] Fulkerson WJ, Adams NR, Gherardi PB. Ability of castrate male sheep treated with oestrogen or testosterone to induce and detect oestrus in ewes. Appl Anim Ethol 1981, 7: $57-66$.

[18] Rosa HJD, Juniper DT, Bryant MJ. Effects of recent sexual experience and melatonin treatment of rams on plasma testosterone concentration, sexual behaviour and ability to induce ovulation in seasonally anoestrous ewes. J Reprod Fertil 2000, 120: 169-176.

[19] Perkins A, Fitzgerald JA. The behavioural component of the ram effect: the influence of ram sexual behavior on the induction of estrus in anovulatory ewes. J Anim Sci 1994, 72: 51-55.

[20] Walkden-Brown SW, Restall BJ, Henniawati. The male effect in Australian cashmere goats 3. Enhancement whit buck nutrition and use of oestrous females. Anim Reprod Sci 1993, 32: 69-84.

[21] Knight TW, Lynch PR. The pheromones from rams that stimulate ovulation in the 
ewe. Proc Aust Soc Anim Prod 1980, 13: 74-76.

[22] Cohen-Tannoudji J, Locatelli A, Signoret JP. Non pheromonal stimulation by the male on $\mathrm{LH}$ release in the anoestrous ewe. Physiol Behav 1986, 36: 921-924.

[23] Signoret JP. The influence of the ram effect on the breeding activity of ewes and its underlying physiology. In: Oldham CM, Martin GB, Purvis IW (Eds), Reproductive physiology of merino sheep, University of Western Australia, 1990, p 59-70.

[24] Over R, Cohen-Tannoudji J, Dehnhard M, Claus R, Signoret JP. Effect of pheromones from male goats on $\mathrm{LH}$-secretion in anoestrous ewes. Physiol Behav 1990, 48: 665668.

[25] Claus R, Over R, Dehnhard M. Effect of male odour on LH secretion and the induction of ovulation in seasonally anoestrous goats. Anim Reprod Sci 1990, 22: 27-38.

[26] Signoret JP. Rôle des différentes informations sensorielles dans l'attraction de la femelle en oestrus par le mâle chez les porcins. Ann Biol Anim Bioch Biophys 1974, 14: 747-755.

[27] Brockway BF. Stimulation of ovarian development and egg laying by male courtship vocalization in budgerigars (Melopsittacus undulatus). Anim Behav 1965, 13: 575-578.

[28] Hinde RA, Steele E. The influence of day length and male vocalizations on the estrogen-dependent behavior of female canaries and budgerigars, with discussion of data from other species. In: Rosenblatt JS, Hinde RA, Beer C, Bunsel M (Eds), Advances in the Study of Animal Behavior, Academic Press, New York, 1978, p 39-73.

[29] McComb K. Roaring by red deer stags advances the date of oestrus in hinds. Nature 1987, 330: 648-649.

[30] Delgadillo JA, Fitz-Rodríguez, Duarte G, Véliz FG, Carrillo E, Flores JA, Vielma J, Hernandez H, Malpaux B. Management of photoperiod to control caprine reproduction in the subtropics. Reprod Fertil Dev 2004, 16: 471-478.

[31] Lindsay DR, Signoret JP. Influence of behaviour on reproduction. In: Proc 9th Int Congress of Animal Reproduction and Artificial Insemination, Madrid, 1980, p 83-92.

[32] Chemineau P. Effect on oestrus and ovulation of exposing Creole goats to the male at three times of the year. J Reprod Fertil 1983, 67: $65-72$.
[33] Restall BJ. Seasonal variation in reproductive activity in Australian goats. Anim Reprod Sci 1992, 27: 305-18.

[34] Mellado M, Hernandez JR. Ability of androgenised goat wethers and does to induce estrus in goats under extensive conditions during anestrus and breeding seasons. Small Rumin Res 1996, 23: 34-42.

[35] Lincoln GA, Short RV. Seasonal breeding: nature's contraceptive. Recent Prog Horm Res 1980, 36:1-52.

[36] Delgadillo JA, Leboeuf B, Chemineau P. Decrease in the seasonality of sexual behavior and sperm production in bucks by exposure to short photoperiodic cycles. Theriogenology 1991, 36: 755-770.

[37] Delgadillo JA, Chemineau P. Abolition of the seasonal release of luteinizing hormone and testosterone in Alpine male goats (Capra hircus) by short photoperiodic cycles. J Reprod Fertil 1992, 94: 45-55.

[38] Sánchez D. Influencia del sistema de explotación sobre el comportamiento sexual de los machos cabríos Criollos de la Comarca Lagunera. Tesis de Maestría. Universidad Autónoma Agraria Antonio Narro, 2003, p 49.

[39] Delgadillo JA, Canedo GA, Chemineau P, Guillaume D, Malpaux B. Evidence for an annual reproductive rhythm independent of food availability in male Creole goats in subtropical northern Mexico. Theriogenology 1999, 52: 727-737.

[40] Delgadillo JA, Carrillo E, Morán J, Duarte $\mathrm{G}$, Chemineau P, Malpaux B. Induction of sexual activity of male Creole goats in subtropical northern Mexico using long days and melatonin. J Anim Sci 2001, 79: 22452252.

[41] Véliz FG, Moreno S, Duarte G, Vielma J, Chemineau P, Poindron P, Malpaux B, Delgadillo, JA. Male effect in seasonally anovulatory lactating goats depends on the presence of sexually active bucks, but not estrous females. Anim Reprod Sci 2002, 72 : 197-207.

[42] Delgadillo JA, Flores JA, Véliz FG, Hernández HF, Duarte G, Vielma J, Poindron, P, Chemineau, P, Malpaux, B. Induction of sexual activity of lactating anovulatory female goats using male goats treated only with artificially long days. J Anim Sci 2002, 80: 2780-2786.

[43] Flores JA, Hernández H, Martínez de la Escalera G, Malpaux B, Delgadillo JA, Poindron P. Artificial long days are sufficient for induction of sexual behavior in male 
goats during the spring period of sexual inactivity. In: Gruner L, Chebert Y (Eds), Proc 7th Int Conference on Goats, Tours, 2000, p 446.

[44] Delgadillo JA, Fitz-Rodríguez G, López JC, Véliz FG, Duarte G, Hernández H. Flores, JA. Stimulation of sexual activity of females goats maintained in extensive conditions when exposed to sexual active males. Reprod Dom Anim 2005, 40: 347.

[45] Tomás R. Estimulación de la actividad sexual de las cabras mediante la introducción de machos tratados únicamente con días largos. Tesis de Licenciatura, Universidad Autónoma Agraria Antonio Narro, 2003, p 35.

[46] Moreno M. Respuesta de las cabras Criollas anovulatorias al efecto macho en el mes de mayo. Tesis de Licenciatura, Universidad Autónoma Agraria Antonio Narro, 2005, p 30.

[47] Barrios C. Los machos cabríos son capaces de estimular la actividad estral de las cabras Criollas anovulatorias durante el mes de junio. Tesis de Licenciatura, Universidad Autónoma Agraria Antonio Narro, 2005, p 31.

[48] Cohen-Tannoudji J, Einhorn J, Signoret JP. Ram sexual pheromone: first approach of chemical identification. Physiol Behav 1994, 56: 955-961.

[49] Vielma J, Hernandez H, Véliz FG, Flores JA, Duarte G, Chemineau, P, Malpaux B, Delgadillo JA. Effect of sedation of does on LH release in does submitted to buck. In: Casey N (Ed), Proc 8th Int Conference on Goats, Pretoria, 2004, p 147.

[50] Vielma J, Hernandez H, Véliz FG, Flores JA, Duarte G, Malpaux B, Delgadillo JA. Buck vocalizations stimulate estrous behavior in seasonal anovulatory female goats. Reprod Dom Anim 2005, 40: 360.

[51] Rivas-Muñoz R, Véliz FG, Vielma J, Delgadillo J. Continuous presence of the bucks is not necessary to induce a male effect in goats. Reprod Dom Anim 2005, 40: 348.

[52] Véliz FG, Poindron $P$, Malpaux B, Delgadillo JA. Maintaining contact with bucks does not induce refractoriness to the male effect in seasonally anestrous female goats. Anim Reprod Sci 2006, 92: 300-309.

[53] Véliz FG, Vélez LI, Flores JA, Duarte G, Poindron P, Malpaux B, Delgadillo JA. La presencia del macho en un grupo de cabras anéstricas no impide su respuesta estral a la introducción de un nuevo macho. Vet Méx 2004, 35: 169-178.

To access this journal online: www.edpsciences.org 